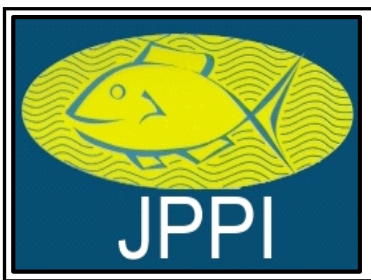

Tersedia online di: http://ejournal-balitbang.kkp.go.id/index.php/jppi e-mail:jppi.puslitbangkan@gmail.com

JURNAL PENELITIAN PERIKANANINDONESIA

Volume 24 Nomor 1 Maret 2018

p-ISSN: 0853-5884

e-ISSN: 2502-6542

Nomor Akreditasi: 653/AU3/P2MI-LIPI/07/2015

\title{
DISTRIBUSI UKURAN PANJANG DAN PARAMETER POPULASI LOBSTER LUMPUR (Panulirus polyphagus Herbst, 1793) DI PERAIRAN SEBATIK, KALIMANTAN UTARA (WPPNRI-716)
}

\section{SIZE DISTRIBUTION AND POPULATION PARAMETERS OF MUD SPINY LOBSTER (Panulirus polyphagus Herbst, 1973) IN SEBATIK WATERS, NORTH KALIMANTAN (IFMA-716)}

\author{
Umi Chodrijah*1, Asep Priatna, dan Duto Nugroho² \\ ${ }^{1}$ Balai Riset Perikanan Laut, Kompl. Raiser JI. Raya Bogor KM. 47, Cibinong, Bogor, Jawa Barat, Indonesia \\ ${ }^{2}$ Pusat Riset Perikanan, JI. Pasir Putih II, Ancol Timur Jakarta Utara, 14430-Indonesia \\ Teregistrasi I tanggal: 14 Maret 2017; Diterima setelah perbaikan tanggal: 17 Januari 2018; \\ Disetujui terbit tanggal: 25 Januari 2018
}

\begin{abstract}
ABSTRAK
Sumberdaya udang barong lumpur (Panulirus polyphagus Herbst, 1793) atau dalam bahasa lokal dikenal sebagai lobster Pakistan telah dimanfaatkan sebagai salah satu komoditas yang bernilai ekonomis di perairan pulau Sebatik, Kalimantan Utara. Data statistik perikanan menunjukkan produksi udang barong di perairan Timur Kalimantan tahun 2005 - 2015 meningkat pesat dengan kelipatan 10 kalinya. Terkait dengan fenomena tersebut, penelitian tentang aspek biologi populasi telah dilakukan pada bulan Maret sampai dengan November 2016. Penelitian ini bertujuan untuk mendapatkan parameter populasi sebagai landasan untuk mengetahui status stok pada tingkat pemanfaatan terkini. Hasil penelitian menunjukkan udang betina tertangkap pada ukuran rata-rata $86,9 \pm 8,58 \mathrm{mmCL}$ sedangkan udang jantan pada ukuran 81,5 \pm 9,63 mmCL. Pola pertumbuhan udang jantan dan betina bersifat allometrik negatif $(b<3)$. Estimasi panjang asimtotis $\left(\mathrm{CL}_{\infty}\right)$ sebesar $124,1 \mathrm{~mm}$ dengan laju pertumbuhan $(\mathrm{K})$ 0,598/tahun. Rata-rata ukuran pertama tertangkap $\left(\mathrm{CL}_{\mathrm{c}}\right)$ adalah $84,5 \mathrm{mmCL}$. Nilai tersebut lebih rendah dari pertama kali matang gonad $\left(\mathrm{CL}_{m}\right)$ sebesar $90,74 \mathrm{mmCL}$. Laju kematian total $(Z)$ sebesar 2,26/tahun, laju kematian alamiah (M) 0,87/tahun serta laju kematian akibat penangkapan (F) 1,39/tahun. Estimasi laju eksploitasi cenderung mengarah kepada penangkapan berlebih $(E=0,61)$, oleh karena itu perlu dilakukan tindakan pengelolaan melalui pendekatan pengendalian upaya penangkapan dan pembatasan ukuran minimum yang boleh ditangkap.
\end{abstract}

Kata Kunci: Distribusi ukuran; parameter populasi; Panulirus polyphagus; Pulau Sebatik; Kalimantan Utara

\begin{abstract}
Mud spiny lobster (Panulirus polyphagus Herbst, 1793) or locally known as Pakistan lobster has been exploited as an important economic species in the waters of Sebatik Island, North Kalimantan. The best available capture fisheries statistic on 2005-2015 indicates the production of marine lobster were significantly increased by multiple 10. Based on this phenomenon, observations on biological aspects were carried out during period of March to November 2016. The aim of this study were to estimate of stock status under existing fisheries condition. The result showed that the average size of females was $86.9 \pm 8.58 \mathrm{cmCL}$ and males was $81.5 \pm 9.63 \mathrm{mmCL}$. The growth pattern indicates allometric negative $(b<3)$. Population parameter performed by length based analysis indicates that asymptotic length (CL $\infty)$ was $124.1 \mathrm{mmCL}$ with growth rate $(K)$ of 0.598/ $y r$. The average size of first capture (CL) was estimated at $84.5 \mathrm{mmCL}$. This value was less than average size of first mature $\left(C L_{m}\right)$ of $90.7 \mathrm{cmCL}$. The predicted annual total mortality rates $(Z)$ was
\end{abstract}

Korespondensi penulis:

umichodriyah@yahoo.co.id 
2.26/yr, the natural mortality (M) was $0.87 / y r$, and fishing mortalities (F) was 1.39/yr. The exploitation rates $(E)$ of 0.61 tend to be beyond the sustainable exploitation level. To reduce the fishing mortality, the initiative of specific local management plan on restructuring active fleet and establishing minimum legal size should be implemented.

\section{Keywords: Size distribution; population parameters; Panulirus polyphagus; Sebatik Island;} North Kalimantan

\section{PENDAHULUAN}

Udang barong lumpur atau mud spiny lobster adalah nama perdagangan jenis Panulirus polyphagus. Penamaan lokal jenis ini dikenal sebagai lobster Pakistan. Spesies ini merupakan salah satu jenis udang barong (lobster) yang hidup dan secara geografis tersebar di perairan laut tropis di kawasan Barat Indo Pasifik mulai dari pantai Pakistan, India, Vietnam, Filipina, Indonesia sampai Australia Barat Laut dan Pantai Timur Papua (Williams, 1986; Holthuis, 1991; Chan, 2010).

Pemanfaatan sumber daya udang barong di Indonesia sebagian besar berasal dari kegiatan penangkapan dengan alat tangkap jaring lobster yang dioperasikan di perairan pantai. Perairan Sebatik merupakan salah satu daerah potensial bagi pemanfaatan udang barong di kawasan Timur Kalimantan. Kegiatan pemanfaatan dari tahun ke tahun di kawasan ini cenderung meningkat, dimana fenomena ini digambarkan oleh jumlah trip jaring insang berlapis pada tahun 2005 tercatat jumlah trip sebesar 282 ribu kemudian meningkat menjadi 658 ribu trip pada tahun 2013 (DJPT, 2014).

Produksi yang digambarkan dari statistik perikanan tangkap nasional memberikan informasi bahwa produksi udang barong di perairan Timur Kalimantan pada tahun 2005 sebesar 507 ton (DJPT, 2007) kemudian meningkat dengan kelipatan lebih dari 10 menjadi 6954 ton pada pada tahun 2013 (DJPT, 2014). Peningkatan produksi tersebut berkorelasi dengan intensitas penangkapan udang barong lumpur di perairan ini sehingga diduga berada pada tekanan pemanfaatan yang cukup tinggi.

Ketersediaan data dan informasi perikanan terkait dengan jumlah hasil tangkapan dan karakteristik upaya penangkapan untuk analisis stok spesifik udang barong lumpur relatif terbatas. Untuk itu, telah dilakukan penelitian pada bulan Maret sampai dengan November 2016.

Penelitian bertujuan untuk mengetahui struktur ukuran dan parameter populasi udang barong lumpur yang tertangkap di perairan perbatasan pulau Sebatik. Salah satu pendekatan yang umum digunakan adalah pendugaan tingkat pemanfaatan berbasis data sebaran ukuran panjang.Informasi yang dihasilkan diharapkan akan menjadi salah satu informasi dasar bagi perencanaan pengelolaan sumberdaya udang barong lumpur khususnya di perairan Timur Kalimantan sehingga dapat dimanfaatkan dalam jangka panjang.

\section{BAHAN DAN METODE Lokasi Penelitian}

Penelitian dirancang melalui survey lapang yang didukung oleh pengukuran secara berkala terhadap aspek biologi dengan bantuan enumerator terlatih. Lokasi penelitian berada di tempat pendaratan ikan Kampung Sei Nyamuk dengan posisi geografis $4^{0} 8^{\prime}$ 44" LU; $117^{\circ} 54^{\prime} 48^{\prime \prime}$ BT. Secara geografis kota Sebatik merupakan bagian dari Kabupaten Nunukan, Kalimantan Utara. Kawasan ini merupakan perairan terluar yang berbatasan dengan Malaysia Timur (Gambar 1).

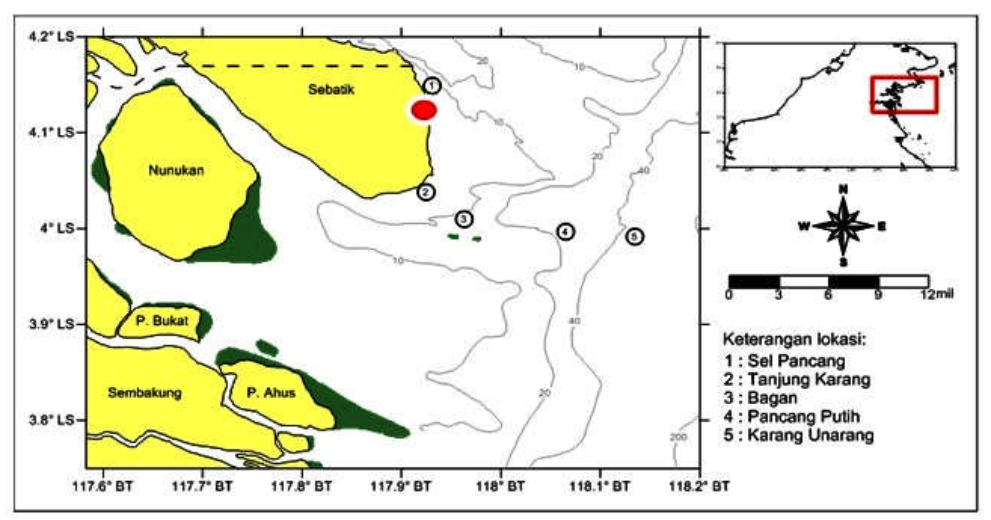

Gambar 1. Lokasi penelitian di Sei Nyamuk, Sebatik, Kabupaten Nunukan, Kalimantan Utara.

Figure 1. Sampling site in Sei Nyamuk, Sebatik, Nunukan regency, North Kalimantan.

Keterangan/Remarks: O Lokasi penelitian/site location 
Pengumpulan data dilakukan terhadap aspek biologi yang terdiri dari panjang karapas $(C L)$, berat individu (W), jenis kelamin dan tingkat kematangan gonada (TKG) selama bulan Maret sampai dengan November 2016. Contoh lobster dikumpulkan dari hasil tangkapan gillnet lobster, berdasarkan Permen KP Nomor 71/PERMEN-KP/2016 dikategorikan sebagai jaring klitik. Kegiatan penangkapan dilakukan dalam skala harian (one-day fishing) menggunakan perahu berukuran $<10 \mathrm{GT}$.

Pengukuran panjang karapas $(\mathrm{CL})$ menggunakan perangkat jangka sorong (caliper), yaitu mulai dari bagian tengah supra orbital sampai di bagian tengah posterior karapas (Holthuis, 1991; Sparre \& Venema, 1999). Pengukuran berat individu digunakan timbangan digital dengan ketelitian $1 \mathrm{gram}$. Penentuan jenis kelamin berdasarkan ciri morfologi udang barong lumpur seperti yang dinyatakan oleh Presscott (2000) \& Chan (2000). Kriteria kematangan gonad didasarkan pada ciri kematangan secara fungsional yaitu dengan mengamati contoh betina yang membawa telurnya (Mac Diarmid \& Sainte-Marie, 2006).

\section{Analisis Data}

Sebaran frekuensi diperoleh dengan mentabulasikan data panjang karapas (CL) dengan selang kelas $5 \mathrm{~mm}$. Selang kelas diadopsi berdasarkan kriteria yang dikemukakan Holden \& Raitt (1974) yang menyatakan bahwa pengelompokkan ukuran $5 \mathrm{~mm}$ ini secara umum digunakan pada kelompok jenis ikan dengan ukuran panjang kurang dari $30 \mathrm{~cm}$.

Nilai panjang karapas lobster pertama kali tertangkap $\left(\mathrm{CL}_{\mathrm{c}}\right)$ diperoleh melalui pendekatan fungsi logistik dengan persamaan Sparre \& Venema, (1992):

$$
\mathrm{S}_{\mathrm{CL}}=\frac{1}{1+\exp \left(\mathrm{a}-\mathrm{b}^{*} \mathrm{CL}\right)}
$$

Dimana: $\mathrm{S}_{\mathrm{CL}}$ adalah selektivitas alat tangkap, a dan b adalah konstanta, $C L$ adalah panjang karapas lobster dan nilai $\mathrm{CL}_{\mathrm{c}}$ diperoleh dari a/b.

Perimbangan nisbah kelamin untuk mengetahui keseimbangan populasi jantan dan betina dilakukan dengan uji Chi-kuadrat (Steel \&Torrie, 1993);

$\mathrm{Chi}^{2}=\sum_{\mathrm{i}-1}^{\mathrm{k}} \frac{(\mathrm{Oi}-\mathrm{Ei})^{2}}{\mathrm{Ei}}$

dimana;

$\mathrm{O}_{i}=$ nilai observasi,

$\mathrm{E}_{\mathrm{i}}=$ nilai harapan dan

$\mathrm{K}=$ jumlah pengukuran
Hubungan panjang - berat lobster dihitung dengan persamaan eksponensial sebagai berikut (King, 2007):

$\mathrm{W}=\mathrm{aCL}{ }^{\mathrm{b}}$.

Parameter "a" adalah koefisien proporsionalitas untuk berat terhadap panjang karapas lobster dan "b" adalah koefisien untuk bentuk tubuh (Freitas et al., 2017). Nilai koefisien "b" setiap spesies berkisar antara 2.5 - 3.5 (Froese, 2006).

Pendugaan paramater populasi dilakukan dengan pendekatan pengkajian stok berbasis ukuran panjang seperti dikemukakan oleh (Pauly, 1983; Sparre \& Venema, 1999; King, 2007). Estimasi panjang karapas asimtotik $\left(\mathrm{CL}_{\infty}\right)$ dan koefisien pertumbuhan $(\mathrm{K})$ dihitung menggunakan pendekatan pergeseran bulanan modus ukuran panjang. Setiap modus diturunkan dengan metoda Battacharya (1967) dalam Sparre \& Venema, (1999).

Estimasi laju pertumbuhan (growth rate) dihitung melalui laju pergeseran modus ukuran panjang (pada selang waktu atau umur tertentu) melalui persamaan:

$$
\frac{\Delta C L}{\Delta t}=\frac{C L(t+\Delta t)-C L(t)}{\Delta t}=\frac{C L_{t}-C_{t-1}}{t-t_{1}}
$$

Dengan menggunakan persamaan linier, maka hubungan antara variabel bebas pertambahan panjang per satuan waktu (bulan) (dL/dt) terhadap variabel terikat rerata panjang pada waktu tersebut menurut Sparre \& Venema, (1999) menjadi :

$$
\frac{\Delta \mathrm{CL}}{\Delta \mathrm{t}}=\mathrm{a}+\mathrm{b}^{*} \mathrm{CL}(\mathrm{t})
$$

dimana;

$\mathrm{a}=$ konstanta intersep dan

$\mathrm{b}=$ koefisien regresi

Hubungan linier diturunkan dari persamaan von Bertalanffy sebagi berikut:

$$
\frac{\Delta \mathrm{CL}}{\Delta \mathrm{t}}=\mathrm{K} *(\mathrm{CL} \infty-\mathrm{CLt})
$$

dimana;

$\mathrm{K}=-\mathrm{b}$ dan $\mathrm{CL}_{\infty}=-\mathrm{a} / \mathrm{b}$

$\mathrm{K}=$ estimasi laju pertumbuhan;

$\mathrm{CL}_{\infty}=$ panjang asimtosis.

Estimasi hubungan umur dengan ukuran panjang mengikuti persamaan:

$C L_{t}=C L \infty *\left(1-e^{\left(-K^{*}(t-t o)\right.}\right)$ 
Pendugaan nilai $t_{0}$ (umur pada saat 0 tahun) berdasarkan persamaan Pauly (1984) :

$\log \left(-t_{0}\right)=0,3922-0,2752 \log \left(C L_{\infty}\right)-1,038 \log (K) . .(8)$

Ukuran saat pertama kali matang gonada didefinisikan sebagai panjang karapas ketika 50\% dari populasi lobster berada pada status matang gonad. Pendugaan ukuran pertama matang gonad (length at first maturity/ $\mathrm{L}_{\mathrm{m}}$ ) dilakukan dengan mengacu prosedur Sperman - Karber yang dilakukan Udupa (1986) melalui perhitungan nilai logaritma pertambahan kumulatif nilai tengah sebagai berikut:

$$
\mathrm{m}=\mathrm{X}_{\mathrm{k}}+\frac{\mathrm{x}}{2}-\left(\mathrm{x} \sum_{\mathrm{i}=1}^{\mathrm{n}} \mathrm{pi}\right)
$$

dimana;

$\mathrm{m}=$ logaritma panjang pertama matang gonada

$X_{k}=$ logaritma kelas panjang ukuran pada saat $100 \%$ matang gonada.

$X=$ selisish logaritma dari pertambahan nilai tengah panjang

$p_{\mathrm{i}}=$ proporsi matang gonad pada kelompok ukuran ke-i.

Panjang pertama kali matang gonad diperoleh dengan mengantilogkan nilai $m$. Panjang pertama kali tertangkap (length at first capture, $\mathrm{CL}_{\mathrm{c}}$ ) diperoleh dari 50\% kumulatif frekuensi ukuran.

Laju mortalitas alami (M) diduga dengan mengaplikasikan persamaan empiris dari Pauly (1980) yaitu: $\log (M)=-0,0066 \quad-\quad 0,279 \quad * \quad \log$ $(\mathrm{CL} \infty)+0,6543^{\star} \log (\mathrm{K})+0,4634^{\star} \log (T) . .(10)$ dimana;

$$
\begin{array}{ll}
\mathrm{CL} \infty & =\text { panjang asimtotik }(\mathrm{mmCL}) \\
\mathrm{K} & =\text { kecepatan pertumbuhan } \\
\mathrm{T} & =\text { suhu perairan rata-rata di } \\
& \text { lokasi }\left(=30^{\circ} \mathrm{C}\right)
\end{array}
$$

Estimasi mortalitas total ( $\mathrm{Z}$ ) diperoleh dari kurva hasil tangkapan berdasarkan ukuran panjang (length converted catch curve) (Pauly, 1983). Koefisien mortalitas penangkapan $(F)$ dihitung dari persamaan:

$$
\mathrm{F}=(\mathrm{Z}-\mathrm{M})
$$

Laju eksploitasi (E) merupakan nisbah mortalitas akibat penangkapan ikan terhadap mortalitas total dihitung mengikuti persamaan:

$E=F / Z$

\section{HASIL DAN BAHASAN \\ Hasil}

\section{Distribusi Ukuran}

Pengumpulan data panjang karapas dan berat udang barong lumpur ( $P$. polyphagus) selama observasi diperoleh sejumlah 921 ekor. Diperoleh contoh udang betina sebanyak 493 ekor dengan kisaran panjang antara

\begin{tabular}{|c|c|c|c|c|c|c|c|c|c|c|c|c|c|c|c|c|c|c|c|c|}
\hline & \multicolumn{4}{|c|}{ Maret/March } & \multicolumn{4}{|c|}{ April/April } & \multicolumn{4}{|c|}{ Mei/May } & \multicolumn{4}{|c|}{ Juni/June } & \multicolumn{4}{|c|}{ Juli/July } \\
\hline & $\mathrm{CLj}$ & Clw & $\mathrm{Wj}_{\mathrm{j}}$ & $\mathrm{Wb}$ & $\mathrm{CLj}$ & Clw & $W_{j}$ & $\mathrm{~Wb}$ & CLj & CLw & $w_{j}$ & Wb & $\mathrm{CLj}$ & CLw & $w_{j}$ & $\mathrm{~Wb}$ & $C L j$ & CLw & $W_{j}$ & $\mathrm{~Wb}$ \\
\hline$n$ & 44 & 40 & 44 & 40 & 54 & 78 & 54 & 78 & 60 & 44 & 104 & 44 & 61 & 78 & 61 & 78 & 19 & 18 & 19 & 18 \\
\hline $\mathrm{mx}$ & 109 & 110 & 850 & 972 & 95 & 107 & 595 & 886 & 109 & 106 & 883 & 883 & 105 & 109 & 843 & 975 & 93 & 97 & 503 & 702 \\
\hline \begin{tabular}{|l|}
$\mathrm{mn}$ \\
\end{tabular} & 54 & 66 & 120 & 260 & 55 & 69 & 114 & 260 & 54 & 52 & 109 & 109 & 64 & 66 & 181 & 238 & 62 & 73 & 178 & 333 \\
\hline $\mathrm{x}$ & 80 & 81 & 393 & 474 & 79 & 86 & 369 & 500 & 78 & 85 & 418 & 493 & 82 & 88 & 397 & 497 & 77 & 83 & 334 & 457 \\
\hline$s$ & 9 & 9 & 133 & 144 & 8 & 8 & 104 & 130 & 10 & 12 & 168 & 175 & 9 & 9 & 139 & 148 & 7 & 7 & 83 & 119 \\
\hline
\end{tabular}
52-110 $\mathrm{mmCL}$ (rata-rata 86,9 \pm 8,58 $\mathrm{mmCL}$ ) dan udang

\begin{tabular}{|c|c|c|c|c|c|c|c|c|c|c|c|c|c|c|c|c|}
\hline & \multicolumn{4}{|c|}{ Agustus/August } & \multicolumn{4}{|c|}{ September/September } & \multicolumn{4}{|c|}{ Oktober/October } & \multicolumn{4}{|c|}{ Nopember/November } \\
\hline & $C L j$ & CLw & $W_{j}$ & Wb & CLj & CLw & Wj & $\mathrm{Wb}$ & CLj & CLw & $\mathrm{Wj}$ & $\mathrm{Wb}$ & $\mathrm{CLj}$ & CLW & $W_{j}$ & $\mathrm{~Wb}$ \\
\hline$n$ & 36 & 47 & 36 & & 50 & 00 & 5 & & 51 & 3 & & & 3 & 2 & 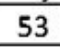 & 2 \\
\hline $\mathrm{mx}$ & 109 & 101 & 1 & & 109 & 106 & 1 & & 109 & 106 & & & 106 & 6 & & 52 \\
\hline $\mathrm{mn}$ & 67 & 72 & 2 & 2 & 67 & 78 & 3 & 350 & 67 & 74 & - & 35 & 5 & 4 & $\underline{5}$ & 349 \\
\hline$x$ & 82 & 85 & 450 & 51 & 8 & 89 & 450 & 5 & 86 & 90 & 48 & & 84 & 89 & 467 & 558 \\
\hline & 12 & 8 & 199 & 129 & 9 & 7 & 171 & 149 & 9 & 7 & 162 & 14 & 9 & 7 & 140 & 124 \\
\hline
\end{tabular}
jantan sebanyak 428 ekor dengan kisaran antara 53,8-109,0 $\mathrm{mmCL}$ (rata-rata $81,45 \pm 9,63 \mathrm{mmCL}$ ) (Tabel 1).

Tabel 1. Jumlah sampel, panjang karapas dan berat individu udang barong lumpur

Table 1. Number of samples carapace lenath and individual weiaht of mud lobster

Keterangan/Remarks:

$\mathrm{n} \quad=$ jumlah sampel/number of sample; $\mathrm{CLj}=$ panjang karapas jantan/male carapace length $(\mathrm{mm})$;

$\mathrm{CLb}=$ panjang karapas betina $(\mathrm{mm}) /$ female carapace length $(\mathrm{mm}) ; \mathrm{Wj}=$ berat jantan/male weight $(\mathrm{g})$;

$\mathrm{Wb}=$ berat betina/female weight $(\mathrm{g}) ; \mathrm{mx}=$ maksimum $/$ maximum; $\mathrm{mn}=$ minimum $/ \mathrm{minimum} ; \mathrm{x}=\mathrm{rerata} /$ average; $\mathrm{s}=$ simpangan baku/standard deviation. 
Perimbangan komposisi ukuran udang yang tertangkap memperlihatkan udang jantan cenderung lebih kecil dibandingkan betina (Gambar 2). Panjang karapas antara jantan dan betina menunjukkan rerata yang berbeda nyata dengan nilai $t_{\text {hitung }}(9,03)>t_{\text {tabel }}$ pada tingkat kepercayaan $95 \%$.

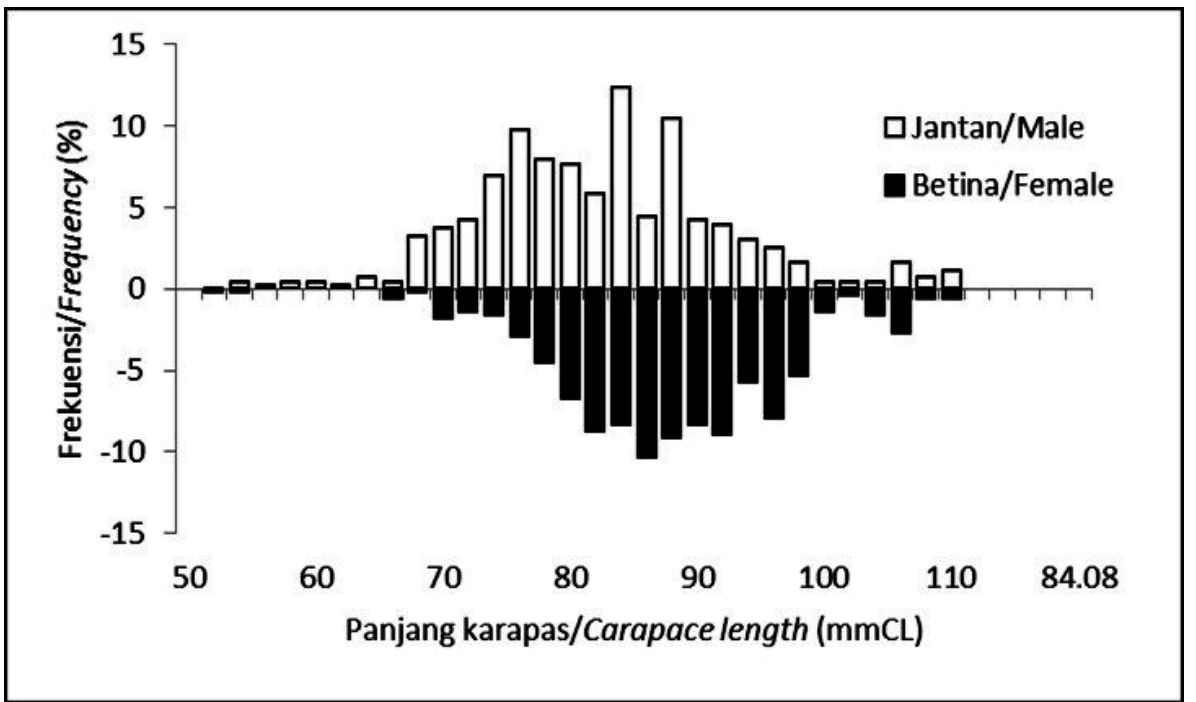

Gambar 2. Distribusi frekuensi panjang karapas udang barong lumpur di perairan Sebatik, Maret- November 2016.

Figure 2. Carapace length frequency distribution of mud spinny lobster in Sebatik waters, March - November 2016.

\section{Hubungan Panjang dan Berat}

Hubungan panjang karapas dan berat udang barong lumpur betina berdasarkan 493 sampel diperoleh nilai koefisien $a=0,0025$ dan nilai $b=2,7363\left(r^{2}=0,902\right)$. Pada kelompok udang jantan sebanyak 428 sampel diperoleh koefisien $a=0,0013$ dan nilai $b=2,8657\left(r^{2}\right.$
$=0,9356)$. Uji komparatif terhadap koefisien bentuk tubuh (b) didapatkan nilai kurang dari $3\left(\mathrm{t}_{\text {hit }}=9,03\right.$; $p>0,05)$. Hasil ini menunjukkan pola pertumbuhan udang jantan maupun betina bersifat allometrik negatif yaitu pertambahan berat lebih lambat dibanding pertambahan panjangnya. Grafik hubungan panjangberat udang barong dijelaskan pada Gambar 3.

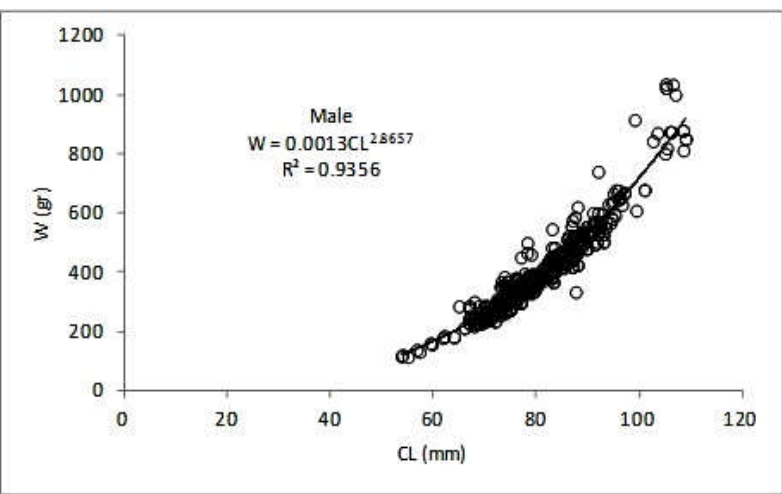

Gambar 3. Hubungan panjang karapas dan berat udang barong lumpur (Panulirus polyphagus) betina (kiri) dan jantan(kanan).

Figure 3. Length-weight relationship of mud spinny lobster (Panulirus polyphagus) female (left) and male (right).

Rata-Rata Ukuran Tertangkap (CL- ${ }_{50 \%}$ ).

Analisis rata-rata panjang karapas yang masuk dalam perikanan $\left(\mathrm{CL}_{\mathrm{c}}\right)$ dihitung berdasarkan sebaran ukuran panjang karapas yang tertangkap. Hasil estimasi tersebut memberikan nilai sebesar 84,03 $\mathrm{mmCL}$ (Gambar 4). 


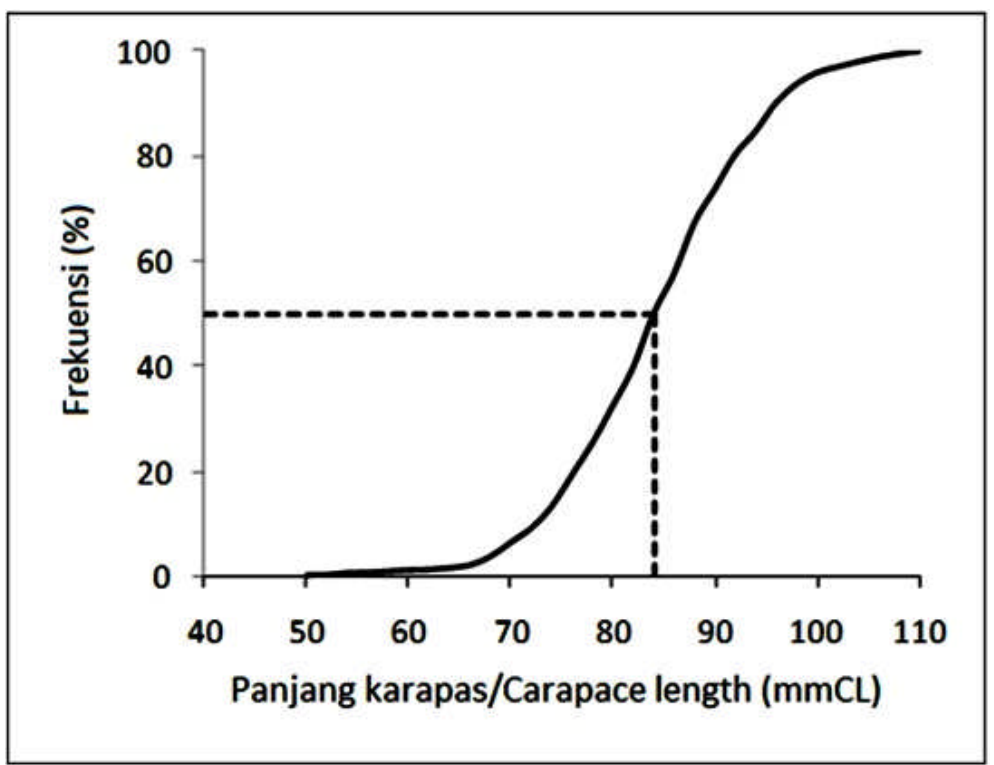

Gambar 4. Panjang rata-rata (50\% kumulatif) udang barong lumpur.

Figure 4. The average length (50\% cumulative) of mud spinny lobster.

\section{Nisbah Kelamin dan Estimasi Pertama Matang Gonad $\left(C L_{m}\right)$}

Nisbah kelamin jantan dan betina pada penelitian ini menunjukkan hasil sebagai 1:1,15 dengan persentase $46 \%$ jantan dan $54 \%$ betina. Berdasarkan uji Chi-kuadrat dengan tingkat kepercayaan 95\% ( $\alpha$ $=0,05)$ diperoleh nilai $t_{\text {hitung }}(4,59)>t_{\text {tabel }}(3,84)$ sehingga nisbah kelamin jantan dan betina berada dalam kondisi tidak seimbang.

Estimasi rata-rata pertama kali matang gonad dengan menggunakan data sebagaimana pada Lampiran 2 dan persamaan (9) diperoleh ukuran sebesar $90,74 \mathrm{mmCL}$. Hasil analisis menunjukkan bahwa ukuran pertama tertangkap $\left(\mathrm{CL}_{c}\right)=84,03 \mathrm{mmCL}$ lebih kecil dari pertama matang gonada $\left(\mathrm{CL}_{\mathrm{m}}\right)=90,74$ $\mathrm{mmCL}$. Kedua estimasi tersebut menunjukkan bahwa aktivitas perikanan cenderung menangkap kelompok umur yang belum matang gonada.

\section{Laju Pertumbuhan}

Parameter pertumbuhan diperoleh dengan cara melacak pergeseran modus data frekuensi panjang karapas bulanan. Selanjutnya garis yang melalui modus paling banyak akan menggambarkan pola pertumbuhannya (Gambar 5).

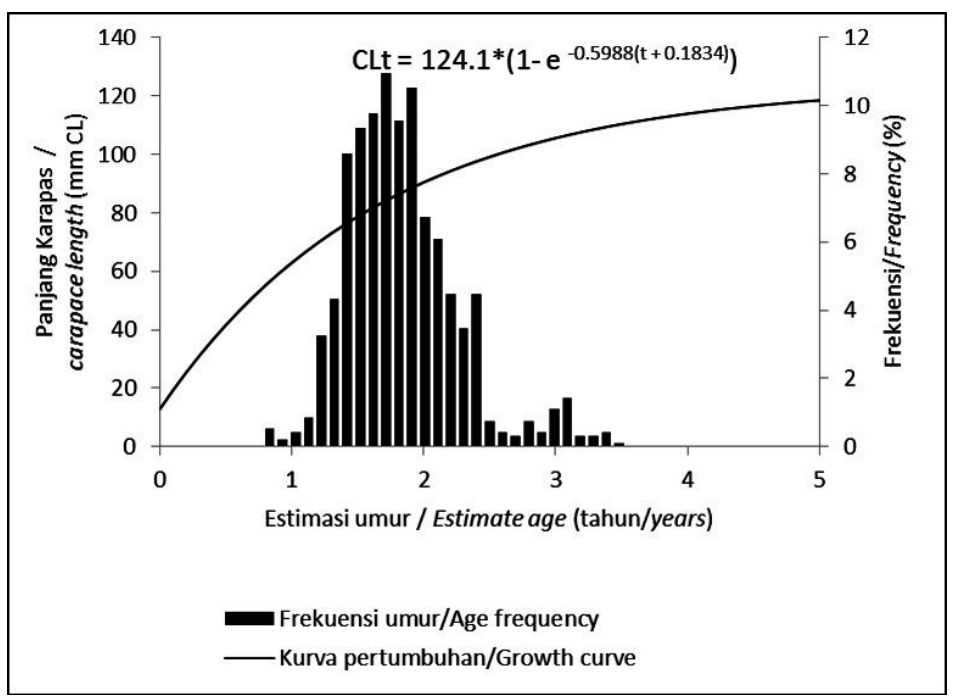

Gambar 5. Kurva pertumbuhan udang barong lumpur (P. polyphagus) dan sebaran ukuran yang tertangkap dari perairan Sebatik.

Figure 5. Growth curve of mud spinny lobster (P. polyphagus) and size distribution of lobster caught in Sebatik waters. 
Kurva tersebut memperlihatkan bahwa pemanfaatan udang barong berlangsung pada kisaran umur yang relatif lebar yaitu antara 1 sampai dengan 4 tahun. Sebaran struktur umur hasil tangkapan didominasi ( $>60 \%$ ) oleh kelompok umur muda $(<2$ tahun).

\section{Laju Kematian dan Eksploitasi}

Nilai laju kematian total (Z) diduga dengan metoda kurva konversi lebar karapas terhadap hasil tangkapan (length converted catch curve) yang yang dihitung dengan memasukkan nilai parameter pertumbuhan $\left(\mathrm{K}, \mathrm{CL} \infty\right.$ dan $\mathrm{t}_{\mathrm{o}}$. Analisis regresi antara umur relatif dan lebar karapas ditampilkan dalam Gambar 6. Diperoleh nilai $Z$ sebagai slope (b) sebesar 2,26/tahun. Laju kematian total tersebut menggambarkan bahwa penurunan jumlah individu dalam satu tahun relatif tinggi sekitar $80 \%$ nya. Dengan menggunakan rata-rata suhu tahunan di perairan Laut Sulawesi sebesar $29^{\circ} \mathrm{C}$, sebagai masukan dalam persamaan (10), maka diperoleh estimasi mortalitas alami (M) sebesar 0.87/tahun.

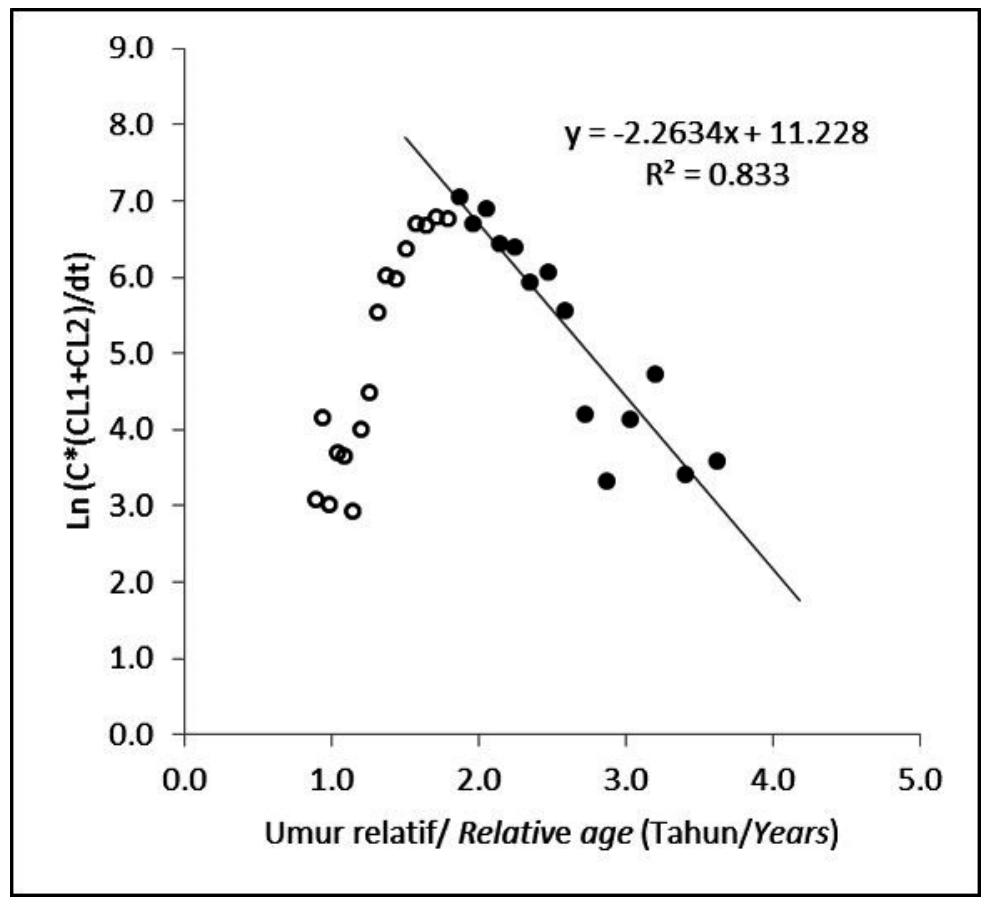

Gambar 6. Kurva hasil tangkapan menurut ukuran panjang udang barong lumpur di perairan Sebatik.

Figure 6. Length base catch curve of mud spinny lobster in Sebatik waters.

Mortalitas penangkapan $(F)$ yang dihitung dari selisih atara nilai nilai Z dan M diperoleh sebesar 1,39/ tahun. Estimasi tingkat pemanfaatan $(\mathrm{E})$ yang merupakan perbandingan antara nilai $F$ dan $Z$ sebagaimana dikemukakan pada persamaan 14 diperoleh hasil sebesar $0,61 /$ tahun.

\section{Bahasan}

Prediksi status stok dapat dilakukan melalui berbagai pendekatan baik melalui kajian sistematik dengan struktur data bio-eksploitasi yang lengkap maupun dengan data terbatas yang akan menghasilkan indikator pemanfaatan (Dowling et al., 2015; Johnson et al., 2017). Kelengkapan data bagi pengkajian stok di perairan Kalimantan Utara masih terbatas. Untuk itu pengkajian stok dapat dilakukan melalui data ukuran panjang. Cara ini merupakan salah satu penedekatan yang banyak dilakukan di berbagai kawasan terutama di kawasan perairan tropis termasuk Indonesia. Analisis sebaran ukuran panjang ikan (termasuk udang) yang dihimpun secara berkala pada rentang waktu 1 tahun banyak digunakan untuk menduga status stok yang sedang berjalan (Beddington \& Kirkwood, 2005).

Penelitian udang barong lumpur ( $P$. polyphagus) di perairan Sebatik diperoleh ukuran panjang minimum yang lebih panjang dibandingkan dengan perairan lain, yaitu pada panjang $52,0 \mathrm{mmCL}$ untuk udang jantan dan $53,8 \mathrm{mmCL}$ untuk udang betina. Penelitian di Johor Malaysia menemukan panjang karapas berkisar antara 47-113 mmCL (Ikhwanuddin et al., 2014). Sementara di perairan pantai Ayah, Kebumen ditemukan panjang karapas udang berkisar antara 40-69 mm (Kadafi et al., 2006).

Perbedaan ukuran panjang karapas pada aktivitas perikanan yang sejenis diduga disebabkan oleh perbedaan selektivitas alat tangkap yang digunakan, 
sebaran ukuran stok yang tersedia serta tingkah laku di alam (Nielsen et al., 2014). Selain itu, perbedaan kondisi lingkungan perairan dan tekanan penangkapan di masing-masing lokasi diduga memberikan pengaruh terhadap ketersediaan sumber dayanya.

Masih banyaknya ukuran udang berukuran besar di perairan Sebatik mengindikasikan proporsi ukuran kelompok dewasa masih relatif berlimpah. Diperlukan pengelolaan dengan pendekatan kehati-hatian agar keberadaan ukuran udang dewasa tetap terjaga. Beberapa contoh yang dapat dijadikan pola pengelolaan antara lain pada perikanan lobster Amerika (Homarus americanus) di perairan pantai Timur Nova Scotia Amerika Utara yaitu dengan cara menjaga proporsi ukuran udang dewasa. Penetapan ukuran dilakukan melalui pembatasan yang boleh ditangkap setelah berumur lebih dari dua tahun dengan alat tangkap bubu. Penetapan ini ditujukan untuk mempertahankan biomassa induk (Tremblay et al., 2009). Penangkapan udang barong di perairan Queensland pantai timur Australia dilakukan dengan cara menyelam untuk menghindari tertangkapnya ikan yang bukan menjadi target penangkapan (Atfield et al., 2004).

Sebaran ukuran udang barong yang tertangkap selama penelitian di Sebatik berada pada kisaran umur 1-4. Tahun. Frekuensi tertinggi pada kisaran umur 1,5 - 2 tahun yaitu pada umur produktif dimana perkiraan pertama kali memijah pada umur 2 tahun. Ukuran rata-rata panjang karapas udang yang tertangkap $\left(\mathrm{CL}_{\mathrm{c}}\right)$ sebesar 84,03 $\mathrm{mmCL}$ dan panjang pertama kali matang gonad $\left(\mathrm{CL}_{\mathrm{m}}\right)$ sebesar $90,74 \mathrm{mmCL}$. Hal ini memberikan indikasi bahwa aktivitas penangkapan yang sedang berjalan berdampak pada kelompok udang yang belum berpijah.

Komposisi ukuran panjang karapas menunjukkan sebagian besar udang yang tertangkap di perairan Sebatik berada pada kelompok kurang dari separuh panjang maksimum teoritis yang dapat dicapai yaitu 4 tahun. Banyaknya proporsi udang muda pada jangka panjang akan memperkecil potensi biomassa ukuran induk. Hasil analisis memberikan indikasi bahwa populasi induk umumnya berada pada kelompok umur lebih dari 2 tahun. Melihat komposisi ukuran yang tertangkap, maka perlu dilakukan pengendalian terhadap populasi yang berukuran kecil. Upaya Pemerintah untuk mencegah hal tersebut telah dilakukan melalui pembatasan ukuran mata jaring yang digunakan. Ukuran mata jaring (mesh size) yang digunakan harus $\geq 1,5$ inch, panjang tali ris $\geq 500 \mathrm{~m}$ dan ukuran kapal yang digunakan $\geq 10$ GT (Peraturan
Menteri KP No.71/PERMEN-KP/2016). Rendahnya tingkat kepatuhan masih merupakan permasalahan yang sering dijumpai dilapangan.

Nisbah kelamin udang barong lumpur hasil penelitian ini berada dalam keadaan tidak seimbang dan didominasi oleh jenis betina $(1: 1,15)$. Temuan hasil penelitian di perairan Veraval, India menunjukkan bahwa nisbah kelamin udang barong lumpur adalah 261 jantan dan 289 betina atau 1:1,1 (Kizhakudan \& Patel, 2010). Hasil penelitian di kawasan Sassoon Dock dan Kasara Bunder, India pada tahun 1976-1985 memperlihatkan nisbah kelamin tahunan jenis $P$. polyphagus didominasi oleh kelompok betina dengan perbandingan udang jantan dan betina sebagai 1:1 sampai dengan 1:1,4 (Kagwade, 1988). Selanjutnya Effendie (2002) menyatakan bahwa keragaman nisbah kelamin dapat terjadi karena 3 faktor yaitu perbedaan tingkah laku seks, kondisi lingkungan dan lokasi penangkapan. Demikian juga, MacDiarmid (1991) menyatakan bahwa keragaman proporsi jantan dan betina diduga terkait dengan tidak meratanya tekanan pemanfaatan yang berkaitan dengan tingkah laku lobster. Perubahan tingkah laku tersebut antara lain proses pergantian kulit (moulting), masa reproduksi dan aktivitas memangsa (MacDiarmid, 1991; Duarte et al., 2015).

Ukuran pertama kali matang gonad udang barong betina di perairan Sebatik pada panjang karapas 90,74 $\mathrm{mm}$. Perbedaan nilai Lm dipengaruhi oleh tekanan penangkapan (Lappalainen, et al. 2016). Penelitian di Perairan Johor, Malaysia diperoleh kematangan gonad pada ukuran 60,2 mmCL (jantan) dan 65,9 mmCL (betina) (Ikhwanuddin et al., 2014). Sementara di perairan Veraval, India pada ukuran 51-55 mmCL (jantan) dan 51-60 mmCL (betina) (Kizhakudan \& Patel, 2010). Menurut Palut (1993) dalam Kulmiye et al. (2006) ukuran matang gonad pada udang barong lebih tergantung pada umur daripada panjang karapasnya. Pendekatan ini relatif sulit diterapkan karena estimasi umur organisme di perairan tropis masih dilakukan melalui analisis ukuran panjangnya.

Estimasi ukuran pertama matang gonada merupakan indikator penting dalam pengelolaan perikanan. Aktivitas pemanfaatan harus mampu membiarkan induk yang mempunyai ukuran sama atau lebih besar dari ukuran pada saat mencapai kematangan (Sudjastani, 1974; Guzman et al., 2008; Fontoura et al., 2009). Selanjutnya, demikian pula Lappalainena et al., (2016) menyatakan bahwa ukuran pertama matang gonad merupakan indikator dari dampak pemanfaatan sumberdaya ikan. 
Kementerian Kelautan dan Perikanan telah menetapkan lobster yang boleh ditangkap di perairan Indonesia tidak dalam kondisi bertelur atau dengan ukuran sebesar $8 \mathrm{cmCL}$ atau $200 \mathrm{~g}$ perekor (Permen KP Nomor 56/PERMEN-KP/2016). Melihat struktur ukuran hasil tangkapan udang barong yang didaratkan di Sebatik, maka masih diperlukan peningkatan pemahaman oleh para nelayan dan pelaku usaha tentang arti penting ukuran yang dibolehkan untuk menjaga kesehatan populasi lobster. Pemanfaatan sumberdaya ikan/udang akan berlangsung dalam jangka panjang bila pengelolaan dilakukan dengan prinsip membiarkan mega spawners untuk tidak ditangkap, komposisi hasil tangkapan didominasi oleh specimen berukuran lebih bear dari pertama matang gonada dan ukuran tertangkap pada panjang optimum (Froese, 2004).

Laju pertumbuhan udang barong di perairan Sebatik lebih besar hasilnya ( $K=0,59 /$ tahun) dibandingkan dengan hasil penelitian Kizhakudan et al. (2013) di perairan Veraval, India. Dimana memperoleh nilai Kudang barong jantan sebesar 0,46/ tahun dan udang betina 0,38/tahun. Estimasi panjang asimtosis $\left(\mathrm{CL}_{\infty}\right)$ di perairan Sebatik sebesar 124,1 $\mathrm{mmCL}$ atau lebih kecil dibandingkan dengan di perairan Veraval, yaitu udang barong jantan sebesar $135 \mathrm{mmCL}$ dan betina sebesar $124,7 \mathrm{mmCL}$ (Kizhakudan et al., 2013).

Fenomena tersebut memberikan informasi bahwa status tekanan pemanfaatan sebagian besar berlangsung pada kelompok muda. Keadaan ini memberikan indikasi bahwa kelompok umur muda berperan nyata pada hasil tangkapan. Pengabaian dalam jangka panjang terhadap status tersebut akan memberikan pengaruh pada peluang tersedianya populasi induk pada kawasan perairan Sebatik dan sekitarnya. Menipisnya potensi induk akan mempengaruhi proses regenerasi bagi keberlangsungan populasi yang akan memberikan manfaat bagi kehidupan masyarakat pesisir.

Perkiraan status pemanfaatan menunjukkan laju eksploitasi (E) di perairan Sebatik sebesar 0,61. Menurut kriteria Pauly et al. (1983), nilai laju pengusahaan yang rasional dan lestari di suatu perairan berada pada nilai $\mathrm{E}<0,5$ atau paling tinggi pada nilai $E=0,5$. Dengan demikian, laju pengusahaan udang barong lumpur di perairan Sebatik sudah melebihi kondisi optimal yang berarti eksploitasi pada saat ini dalam kondisi berlebih (over exploited). Apabila tidak dilakukan pengendalian laju eksploitasinya, maka dikhawatirkan dalam jangka panjang akan mengakibatkan terancammnya kelestarian dan kesinambungan sumberdaya udang barong lumpur di perairan Sebatik.

Timbulnya indikasi tingginya tekanan pemanfaatan yang dalam jangka panjang akan mempengaruhi proses regenerasi memerlukan tindakan nyata dalam bentuk kebijakan pengelolaan. Salah satu kebijakan yang perlu dilakukan adalah pengendalian hasil tangkapan terhadap kelompok ukuran yang belum berpijah melalui penentuan ukuran minimum yang dapat ditangkap antara lain melalui pelepasan individu berumur muda ketika tertangkap dalam keadaan hidup, demikian juga pembatasan minimum mata jaring yang diizinkan untuk beroperasi untuk menghindari tertangkapnya lobster berumur muda.

\section{KESIMPULAN}

Distribusi ukuran panjang karapas udang barong lumpur (Panulirus polyphagus) betina tertangkap pada ukuran rata-rata $86,9 \pm 8,58 \mathrm{mmCL}$ sedangkan udang jantan pada ukuran $81,5 \pm 9,63 \mathrm{mmCL}$. Pola pertumbuhan udang jantan dan betina bersifat allometrik negatif $(b<3)$. Estimasi panjang asimtotis $\left(C L_{\infty}\right)$ sebesar 124,1 mm dengan laju pertumbuhan (K) 0,598/tahun. Rata-rata ukuran pertama tertangkap $\left(\mathrm{CL}_{\mathrm{c}}\right)$ adalah $84,5 \mathrm{mmCL}$. Nilai tersebut lebih rendah dari pertama kali matang gonad $\left(\mathrm{CL}_{m}\right)$ sebesar 90,74 $\mathrm{mmCL}$. Laju kematian total (Z) sebesar 2,26/tahun, laju kematian alamiah (M) 0,87/tahun serta laju kematian akibat penangkapan (F) 1,39/tahun. Estimasi laju eksploitasi cenderung mengarah kepada penangkapan berlebih $(E=0,61)$, oleh karena itu perlu dilakukan tindakan pengelolaan melalui pendekatan pengendalian upaya penangkapan dan pembatasan ukuran minimum yang boleh ditangkap.

\section{PERSANTUNAN}

Tulisan ini merupakan bagian dari kegiatan penelitian karakteristik biologi perikanan, habitat sumber daya ikan dan potensi produksi sumberdaya perikanan di WPP716 (Laut Sulawesi dan sebelah Utara Pulau Halmahera) pada Balai Penelitian Perikanan Laut Muara Baru, Jakarta Tahun Anggaran 2016. Penulis juga mengucapkan terima kasih kepada petugas enumerator di Sebatik yang telah membantu dalam pengumpulan data selama penelitian. 


\section{DAFTAR PUSTAKA}

Anonimus. (2016). Peraturan Menteri Kelautan dan Perikanan Republik Indonesia No. 56/PERMEN$\mathrm{KP} / 2016$. Tentang larangan penangkapan dan/atau pengeluaran lobster (Panulirus spp.), kepiting (Scylla spp.), dan rajungan (Portunus spp.) dari wilayah negara Republik Indonesia. p. 8.

Anonimus. (2016). Peraturan Menteri Kelautan dan Perikanan Republik Indonesia No. 71/PERMEN-KP/ 2016. Tentang jalur penangkapan ikan dan penempatan alatpenangkapan ikan di wilayah pengelolaan perikanan negara Republik Indonesia. p. 4.

Atfield, J., Turnbull, Gaffney, P., Dunning, M., Weis, A., Bullock, C., Ryan, S., \& Clarke, K. (2004). An ecological assessment of Queensland's East coast tropical rock lobster fishery (p. 37). A report to the Australian Government Department of Environment and Heritage on the ecologically sustainable management of a single-species dive fishery. Queensland Gov. Dept. Primary Industry \& Fisheries.

Beddington, J.R. \& Kirkwood, G.P. (2005).The estimation of potential yield and stock status using life history parameters. Philos. Trans. R. Soc. Lond. Biol. Sci. 360(1453), 163-170.

Chan, T. Y. (2000). Lobster. In Living Marine Resources of the Western Central Pasific. Vol. 2. Cephalopods, crustacean, holothurians, and shark. FAO Species Identification Guide for Fishery Ourposes.FAO Purposes. FAO-Un, Norwegian Agency for International Development. 974-1043.

Chan, T.Y. (2010). Annotated checklist of the world's marine lobster (Crustacea: Decapoda; Astacidea, Glypheidea, Achelata, Polychelida). The Raffles Bulletin of Zoology. Supplement, (23), 153-181.

DJPT, 2007. Statistik perikanan tangkap di laut menurut wilayah Provinsi di Indonesia 2006. Kementerian Kelautan dan Perikanan. 7(1), 83.

DJPT, 2014. Statistik perikanan tangkap di laut menurut wilayah Provinsi di Indonesia 2013. Kementerian Kelautan dan Perikanan. 15(1), 325.

Dowling, N. A., Dichmont, C. M., Haddon, M., Smith, D. C., Smith A.D.M., \& Sainsbury, K. (2015). Empirical harvest strategies for data-poor fisheries: A review of the literature. Fish. Res. 171, 141154.
Duarte, L.F.A., Rodrigues, E.S. Pinheiro, M.A.A., \& Gasalla, M.A. (2015). Slipper lobster (Scyllaridae) off the southeastern coast of Brazil: relatv growth, population structure, and reproductive biology. Fish. Bull. 113, 55-68.

Effendie, M.I. (2002). Biologi perikanan (p. 163). Penerbit Yayasan Pusaka Nusatama. Yogyakarta.

Fontoura, N.F., Braun, A.S., \& Milani, P.C.C. (2009). Estimating size at first maturity (L50) from Gonado somatic Index (GSI) data. Neotrop. Ichthyol. 7 (2), 217-222.

Freitas, T.M.D, Souza, J.B., Prudente, B.S., \& Montag, L.G.A. (2017). Length-weight relationship in ten fish species from the Nhamundá River, the Amazon Basin, Brazil. Acta Amazonica. 47(1), 7578.

Froese, R. (2004). Keep it simple: three indicators to deal with overfishing. Fish and Fisheries. 5, 86-91.

Froese, R. (2006). Cube law, condition factor and weight-length relationships: history, meta-analysis and recommendations. J. Appl. Ichthyol. 22, 241-253.

Guzman, H.M., Cipriani, R., Vega, A.J. Lopez, M., \& Mair, J.M. (2008). Population assessment of the pacific green spiny lobster panulirus gracilis in Pacific Panama. Jour. of Shellfish Research. 27(4), 907-915.

Holden, M.J. \& Raitt, D.F.S. (1974). Manual of fisheries science.Part 2. Methods of resource investigation and their application. FAO Fish. Tech. Pap. 115. (Rev. 1). p. 214.

Holthuis, L.B. (1991). An annotated and illustrated catalogue of marine lobsters known to date. FAO species catalogue, Marine Lobsters of the World. 13, 292.

Ikhwanuddin, M., Fatihah, S.N., Nurul, J.R., Zakaria, M.Z., \& Abol-Munaf, A.B. (2014). Biological Features of Mud Spiny Lobster, Panulirus polyphagus (Herbst, 1793) from Johor Coastal Water of Malaysia. World Applied Sciences Journal. 31 (12), 2079-2086.

Johnson, A.F., Moreno-Báez, M., Giron-Nava, A., Corominas, J., Erisman, B., Ezcurra, E., \& AburtoOropezaet, O. (2017) Correction: A spatial method to calculate small-scale fisheries effort in data poor scenarios. Plos One, 12(6), e0179114. 
Kadafi, M.R., Widaningroem., \& Soeparno. (2006). Aspek biologi dan potensi lestari sumberdaya lobster (Panulirus spp.) di Perairan Pantai Kecamatan Ayah Kabupaten Kebumen. Jurnal Perikanan (J. Fish Science). VIII (1), 108-117.

Kagwade, P.V. (1988). Reproduction in the Spiny Lobster P. Polyphagus (Herbst 1793). Jour. Marine. Biol. Association. India, 1988, 30 (1\&2), 37-46.

King, M. (2007). Fisheries Biology: assessment and management (p. 400). $2^{\text {nd }}$ edition. Blackwell Publishing Ltd.

Kizhakudan, J.K. \& Patel, S.K. (2010). Size at maturity in the mud spiny lobster Panulirus polyphagus (Herbst, 1793). J. Mar. Biol. Ass. India, 52 (2), $170-179$.

Kizhakudan, J.K. \& Patel, S.K. (2013). Growth and moulting in the mud spiny lobster, Panulirus polyphagus (Herbst, 1793). Indian Journal of Fisheries. 60(2),79-86.

Kulmiye, A.J., Mavuti, K.M., \& Groeneveld J.C. (2006). Size at onset maturity of spiny lobster Panulirus homarus at Mambrui, Kenya. African Journal of Marine.Science. 28(1), 51-55.

Lappalainena, A., Saksb, L., Sustarc, M., Heikinheimoa, O., Jurgensb, K., Kokkonena, E., Kurkilahtic, M., Verliinb, A., \& Vetemaa, M. (2016). Length at maturity as a potential indicator of fishing pressure effects on coastal pike perch (Sander lucioperca) stocks in the northern Baltic Sea. Fisheries Research, 174, 47-57.

MacDiarmid. (1991). Seasonal changes in depth distribution, sex ratio and size frequency of spiny lobster Jasus edwardsii on a coastal reef in northern New Zealand. Mar. Ecol. Prog. Series. 70,129-141.

MacDiarmid, A.B. \& Sainte-Marie, B. (2006). Reproduction. In Philips, B.F (Ed.): Lobster: Biology, Management, Aquaculture and fisheries. Blacwell Publishers, 45-77.

Nielsen, J.R., Kristensen, K., Lewy, P., \& Bastardie, F. (2014). A statistical model for estimation of fish density including correlation in size, space, time and between species from research survey data. Plos One. 9(6), e99151.
Pauly, D. (1980). On the interrelationship between natural mortality, grwoth parameters, and mean environmental temperature in 175 fish stocks. $J$. Com. CIEM. 39(2), 175-192.

Pauly, D. (1983). Some simple methods for the assessment of tropical fish Stock. FAO Fish. Tech. Pap. 254, 52.

Pauly, D., Ingles, J., \& Neal, R. (1984). Application to shrimp stocks of objective methods for the estimation of growth, mortality, and recruitment related parameters from length frequency data (ELEFAN I and II). In Penaeid Shrimp-Their Biology \& Management. Fishing News Book. p. 220234.

Presscott, J. (2000). A Handbook for lobster fisherman of the tropical Pacific Island (p. 20). South Pacific Commission. Noumea, New Caledonia.

Sparre, P. \& Venema, S.C. (1999). Introduksi Pengkajian Ikan Tropis.Buku 1. Manual (p. 438). Terjemahan. Pusat Penelitian \& Pengembangan Perikanan Jakarta.

Steel, R.D.G., \& Torrie, J.H. (1993). Prinsip dan prosedur statistika, suatu pendekatan biometrik (p. 748). Terjemahan B. Sumantri. Penerbit PT. Gramedia Pustaka Utama, Jakarta.

Sudjastani, T. (1974). Dinamika populasi ikan kermbung di Laut Jawa. Laporan Penelitian Perikanan Laut. (1), 30-64.

Tremblay, M.J., Macdonald C., \& Claytor, R.R. (2009). Indicators of abundance and spatial distribution of lobsters (Homarus americanus) from standard traps. New Zealand Journal of Marine and Freshwater Research, 43(1), 387-399.

Udupa, K. S. (1986). Statistical method of estimating the size at first maturity in fishes. Fishbyte 4. ICLARM. 8-10.

Williams, A.B. (1986). Lobsters-Identification, World Distribution, and U.S. Trade. Marine Fisheries Review. 48(2), 36. 
Lampiran 1. Sebaran bulanan frekuensi panjang karapas $P$. polyphagus

Appendix 1. Monthly distribution of carapace length frequency of mud spiny lobster, (P.polyphagus)
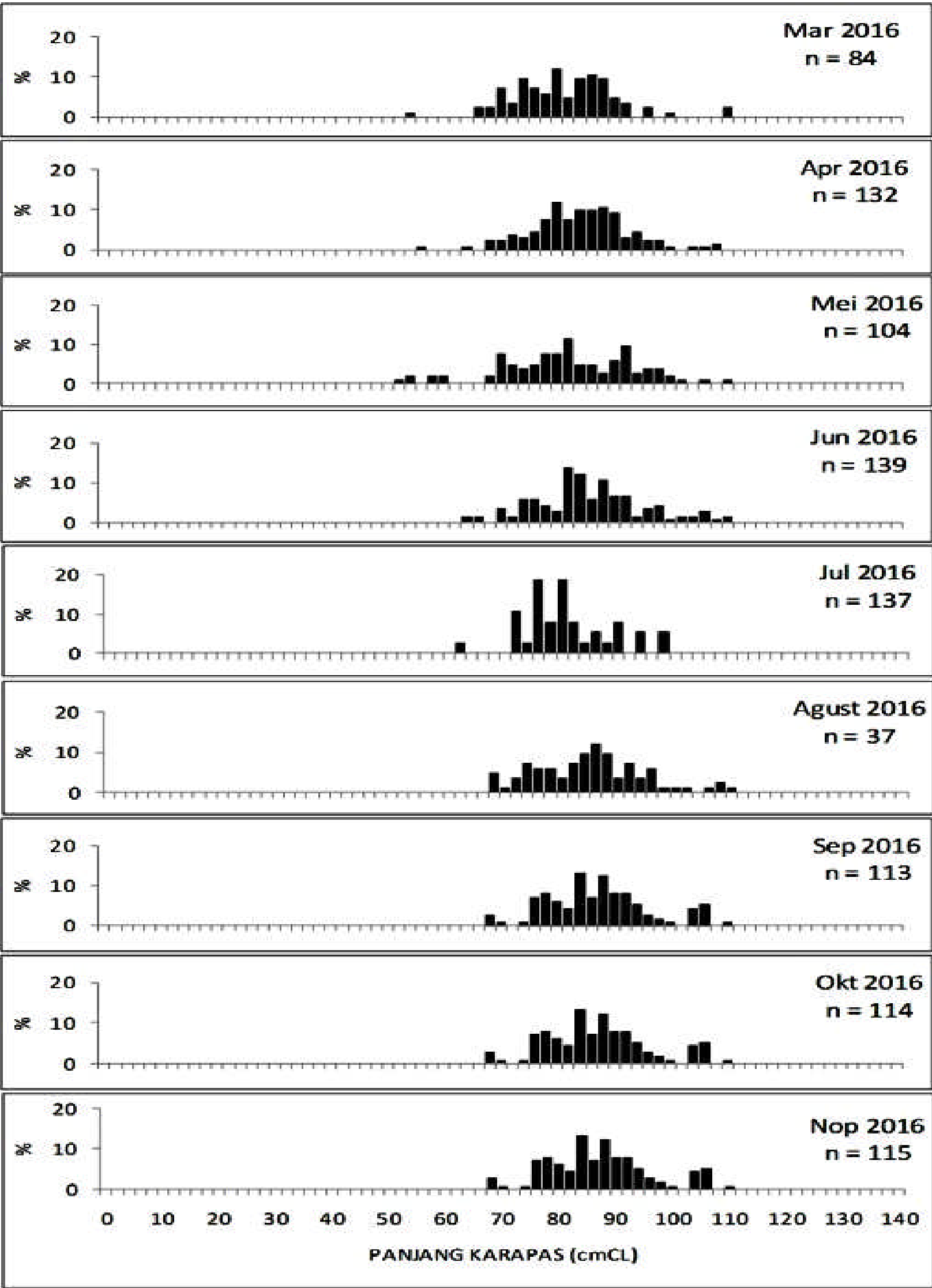
Lampiran 2. Estimasi ukuran pertama matang gonada udang barong lumpur Appendix 2. Estimation of length at first maturity of mud spiny lobster

\begin{tabular}{|c|c|c|c|c|c|c|c|c|c|}
\hline \multirow[b]{2}{*}{ Midlength } & \multirow[b]{2}{*}{\begin{tabular}{|c|} 
Log \\
Midlengt \\
$\mathrm{h}$ \\
\end{tabular}} & \multirow[b]{2}{*}{$\begin{array}{c}\text { No.Samp } \\
\text { le }\end{array}$} & \multicolumn{2}{|c|}{ Maturity stage } & \multirow[b]{2}{*}{$\begin{array}{l}\text { Fully } \\
\text { mature }\end{array}$} & \multirow[b]{2}{*}{$\begin{array}{l}\text { Prop.full } \\
\text { y mature }\end{array}$} & \multirow[b]{2}{*}{$\begin{array}{c}\mathrm{Xi}+1- \\
\mathrm{Xi}=\mathrm{X}\end{array}$} & \multirow[b]{2}{*}{$q i=1-p i$} & \multirow[b]{2}{*}{$\begin{array}{c}(p i . q i) /(n i- \\
\text { 1) }\end{array}$} \\
\hline & & & Immature & Maturing & & & & & \\
\hline & (Xi) & (ni) & & & (ri) & (pi) & & & \\
\hline 54 & 1.732394 & 2 & 2 & 0 & 0 & 0 & 0.031034 & 1 & 0 \\
\hline 58 & 1.763428 & 0 & 0 & 0 & 0 & & 0.028964 & 1 & 0 \\
\hline 62 & 1.792392 & 0 & 0 & 0 & 0 & & 0.027152 & 1 & 0 \\
\hline 66 & 1.819544 & 3 & 3 & 0 & 0 & 0 & 0.025554 & 1 & 0 \\
\hline 70 & 1.845098 & 10 & 10 & 0 & 0 & 0 & 0.024134 & 1 & 0 \\
\hline 74 & 1.869232 & 15 & 15 & 0 & 0 & 0 & 0.022863 & 1 & 0 \\
\hline 78 & 1.892095 & 36 & 34 & 2 & 2 & 0.055556 & 0.021719 & 0.944444 & 0.001499 \\
\hline 82 & 1.913814 & 76 & 72 & 4 & 4 & 0.052632 & 0.020685 & 0.947368 & 0.000665 \\
\hline 86 & 1.934498 & 92 & 82 & 10 & 10 & 0.108696 & 0.019744 & 0.891304 & 0.001065 \\
\hline 90 & 1.954243 & 86 & 79 & 7 & 7 & 0.081395 & 0.018885 & 0.918605 & 0.00088 \\
\hline 94 & 1.973128 & 72 & 63 & 9 & 9 & 0.125 & 0.018098 & 0.875 & 0.00154 \\
\hline 98 & 1.991226 & 65 & 57 & 8 & 8 & 0.123077 & 0.017374 & 0.876923 & 0.001686 \\
\hline 102 & 2.0086 & 9 & 5 & 4 & 4 & 0.444444 & 0.016706 & 0.555556 & 0.030864 \\
\hline 106 & 2.025306 & 21 & 17 & 4 & 4 & 0.190476 & & 0.809524 & 0.00771 \\
\hline & & & & & 48 & 1.181276 & & & 0.045909 \\
\hline & & & & & & & 0.022532 & & \\
\hline
\end{tabular}

$\mathrm{m}=\mathrm{Xk}+\mathrm{X} / 2-(\mathrm{X}$ ? $\mathrm{pi})$

$\mathrm{m}=+(0,025 / 2)-\left(0,025^{\star} 2,065\right)$

$\mathrm{m}=1.9578$

antilog $=$

Panjang lobster pertama kali matang gonad $(\mathrm{Lm})$ $\mathrm{m}=\log$ ukuran ikan saat pertama matang ovarium

$\mathrm{Xk}=\mathrm{Log}$ ukuran ikan dimana $100 \% \mathrm{k}$ an sampel sudah matang $\mathrm{X}=$ selang log ukuran (log size increment $)$

$\mathrm{pi}=$ proporsi ikan matang pada kelompok ke $\mathrm{i}$

$95 \% \mathrm{CL} \quad$ Upper limit Antilog $\left(m+1.96\right.$ Sqrt $(X)$ kwadrat $\left(?\left(\right.\right.$ pi $\left.\left.{ }^{*} q i\right) /(n i-1)\right)$

Low erlimit Antilog ( $m-1.96$ Sqrt (X)kwadrat (?(pi* $\left.\left.{ }^{*}\right)(n i-1)\right)$

$\begin{array}{lrll}\mathrm{mu} & 1.9578 & \text { Antilog }(\mathrm{mu}) & 90.74 \\ \mathrm{ml} & 1.957778 & \text { Antilog }(\mathrm{ml}) & 90.74\end{array}$

